\title{
Geographical breakdown of Polish OFDI - explanatory potential of Uppsala model ${ }^{*}$
}

\author{
Agnieszka Kłysik-Uryszek \\ University of Lodz \\ Poland \\ aklysik@uni.lodz.pl
}

\author{
Anetta Kuna-Marszałek \\ University of Lodz \\ Poland \\ akuna@uni.lodz.pl
}

\begin{abstract}
Last decade proved that internationalization becomes the more and more important growth strategy for Polish companies. The paper attempts to find whether they choose to invest abroad in line with the framework of Uppsala model, i.e.: start to establish foreign entities in one or a few neighbouring countries rather than on distant markets and precede production relocation by establishing trade units. The research provide evidence that Polish firms prefer this conservative model of internationalization. Up to 2011 almost $85 \%$ of all foreign entities were based in Europe while over a half of them (and slightly more than $60 \%$ of industrial companies) were located in the immediate neighbourhood (Germany, the Czech Republic, Slovakia, Ukraine, Belarus, Lithuania, and Russia). Moreover, the highest turnover was also recorded in the closest markets (especially Germany and the Czech Republic). The analysis also shows that in general, the share of manufacturing entities was dominated by trade firms.
\end{abstract}

Keywords: foreign investments, internationalization stage models, Polish manufacturing firms

JEL Classifications: F21, F23

\section{INTRODUCTION}

Since the 1970s the world has witnessed a rapid internationalization of markets, industries and firms. That triggered an emergence of an increasing number of conceptual and empirical studies on international entrepreneurship. The dynamics of changes in the global economy gave birth to new studies on internationalization strategy; numerous theoretical concepts have emerged so far to describe models of

The research is financed by Polish National Science Centre (Project "Determinants and effects of active internationalization of enterprises from the Lodz's region”, UMO-2011/01/B/HS4/03372). 
international expansion of firms. The Uppsala model is one of the most commonly used to study the phenomenon also as a tool to be applied to study Polish firms, which enter foreign markets.

According to the stage approach, companies start selling products in their home markets and then they sequentially look at new countries. The model implies that rather than investing simultaneously in different markets, firms should take small, incremental steps and invest in one of a few of their neighbouring countries. Only later can they enter new markets located further and further away. In other words, firms themselves decide to first expand to markets close to them not only in terms of geographic proximity but also representing similar culture and knowledge advancement.

The paper attempts to investigate the internationalization path of Polish investors, especially from the manufacturing sector, on foreign markets. There are many possible ways of expanding internationally: gradually (stage models), through network cooperation, to being so called born globals, etc. In this article, we decided to address the Uppsala model, as one of the most dominant. Besides, initial observations have shown that Polish companies follow the path of gradual internationalization, hence focusing on it in the context of the above mentioned model seems justified. Therefore, the main hypothesis of the paper is that Polish firms expand geographically in line with the main findings of the Uppsala model of internationalization, which means that they start and continue to invest in neighbouring countries rather than investing in distant markets and/or several markets simultaneously and they choose forms supporting exports and foreign sales first (delocalization of production plants seems subsequent).

The paper starts with an overview of the definitions of internationalisation of enterprises and different theories about internationalization, which focus mainly on the traditional stage approach. The second part validates the main theses of the model using data from manufacturing firms from Poland. The article ends with a quick look at statistical data on Polish OFDI, especially at their geographical breakdown. Main findings are included in concluding remarks.

\section{LITERATURE REVIEW}

Literature offers many definitions of internationalisation of enterprises. The term internationalization' is ambiguous and definitions vary depending on the phenomenon they wish to explain. Welch and Luostarinen (1988) as well as Johanson and Vahlne (1977) describe it as a process of increasing involvement in international operations. Calof and Beamish (1995) stress the need to adapt firm's operations (strategy, structure and resources) to the international environment. Such approach means internationalization may be regarded not merely from the perspective of entering foreign markets, but more broadly, from that of developing and managing international operations (Trąpczynski and Wrona, 2013). Mejri and Umemoto (2010), in turn, take a comprehensive approach to internationalization and stress that it is influenced by various factors (such as firm characteristics, culture, environment, etc.) and state that we can understand internationalization only when we understand all the various factors, which influence the process. Researchers often treat internationalization of companies as a mean to handle exchange relationships and/or to create competitive advantage that facilitates the creation of value and customers' needs satisfaction (Hammond and Groose, 2003). The idea of Dunning eclectic paradigm (1981) is also worth quoting, since it treats internationalization as a model of investing abroad, where a firm uses its own advantages of: ownership, internalisation and localisation.

Some authors (e.g. Gorynia, 2007) distinguish two types of internationalization of companies: active and passive. The first one is understood as a foreign expansion, which may take various forms. Passive internationalisation consists in collaboration and establishing economic links with foreign partners in the 
country, in which the company in question is based. Such an approach demonstrates that international operations can be divided into the following categories: „internal”, „external” and „cooperative”, which provides evidence of the „holistic nature of internationalisation” (Ruzzier, 2010, s. 14 after: Korhonen, 1999) reflected in works of many researchers (see Fletcher, 2001).

Internationalization is understood as a state, i.e., the current stage, degree of internationalization or as a process, i.e., passing through subsequent (higher or lower) stages of internationalization. Static approach uses specific indicators to identify internationalization intensity (e.g. sales, assets, profit, employment, investment). The second approach determines long-term nature of internationalization. Reaching subsequent stages requires enterprises to develop long-term expansion strategies and increase engaged assets. On the other hand, however, internationalization should also be considered in the context of deinternationalization (Welch and Luostarinen, 1988; Calof and Beamish, 1995; Turner 2012), which may take the form of divestment on re-internationalization. The latter phenomenon is the least researched so far.

Increasing interest in internationalization of firms observed at the beginning of the 1960s has led to the emergence of many different approaches and models, which attempted to explain its usual course. Within last 50 years many concepts were conceived. They make references mainly to the theory of enterprise and to theories, which explain changes in organisations. Some authors have openly declared that at present internationalization should be interpreted as a part of an ongoing strategic process of most business firms (Melin 1992).

Major groups of internationalization theories include stage theories of internationalization (Uppsala model and innovative models), early internationalization theories (accelerated, simultaneous and born globals internationalization models) and network theories. Most of them highlight the key determinants of firms' engagement in operations in the markets of third countries, justify the need for international expansion and point to its major consequences. The majority of these theories cannot be universally applied meaning their conclusions do not apply equally across the board. Conclusions depend, inter alia, on the size of an enterprise, the specificity of its industry or the advancement of economic development of its home country. Recently we can observe a tendency to combine various theories in order to explain internationalization and taking a holistic approach to the process.

Since the objective of our analysis is to demonstrate whether the internationalization of Polish companies follows the idea of the Uppsala model, below we discuss the most important conclusions from the original concept. However, before we proceed to them, we will briefly refer to the two remaining groups of models: network models and early internationalisation models.

Models from the first group assume that firms acquire experience from business relations with other firms operating in an international network. Comprehensive review of the main approaches and schools of network was made by Möller and Rajala (2007). Variety of business networks, social and strategic alliances hinder any unambiguous identification. In literature they have been defined in many sorts of ways (Gulati et al., 2002; Fulk 2001). Taking a simplistic view, we may assume they are collections of individual or functionally relatively autonomous operators, differentiated in terms of sectors and geographical locations, which through collaboration become a coherent structure that delivers concrete undertakings. What counts in a network is the market position, relations with counterparts and the possibility to acquire and strengthen resources.

These internationalization models also stress that it is the result of interactions between a company (internal actors) and the network of relationships with customers, competitors, suppliers, consultants and other entities of the international environment (external actors). Networks have also been used to explain the internationalization pursued by SMEs (Ojala, 2009; Ng and Zain, 2006).

Early internationalisation models, in turn, question the sequential and cumulative nature of internationalization as they point to both leapfrogging and to the possibility of firm's simultaneous operations in many foreign markets. In other words, enterprises may decide to substantially engage, e.g. by making foreign 
direct investments, without any earlier experience of economic operations in a given country. They enter many markets at the same time using various forms of internationalization (Andersson and Wictor, 2003; Sharma and Blomstermo, 2003). They are also quite flexible in their choices (Rialp, Rialp and Knight, 2005) and easily adapt to customers' needs and the competition-related requirements.

Unconventional models of internationalization also challenge the importance of psychic and geographic distance and the conviction that international expansion is usually preceded with success in the domestic market. That is often the case of SMEs in technologically advanced industries operating in dynamically developing markets, which continuously evolve. They offer unique and highly specialist products/services, use original know-how and knowledge. In some technologically intensive sectors, such as electronics or ICT products have specific characteristics (e.g. scalability), which may facilitate rapid internationalization of enterprises (Cannone and Ughetto, 2014). Within several years after they were established, born global type businesses expand abroad skipping e.g. the stage of exporting. Entrepreneurs who enter this stage, however, offer their products to many markets at the same time and report much higher increases in sales than the so called "traditional exporters” and continuously deepen their engagement (Sleuwaegen and Onkelinx, 2014).

The above briefly presented network approach and early internationalization models remain somehow in juxtaposition with the Uppsala model, the idea of which was presented by Johanson and WiedersheimPaul (1975) and Johanson and Vahlne (1977). The authors observed that many Swedish companies, but also many companies based in other countries (especially those with small domestic markets), when entering foreign markets typically adopted a stage approach to their involvement abroad. Internationalization of enterprises takes place as a result of "gradual acquisition, integration and use of knowledge about foreign markets and operations, and on the incrementally increasing commitments to foreign markets" (Johanson and Vahlne, 1977, p. 23). In other words, it is the outcome of different types of knowledge acquisition.

The authors claimed that internationalization is a slow and long-lasting process. Besides, it is a consequence of earlier growth and successes in the domestic market followed by expansion to markets in countries the closest in terms of geography, which are similar when it comes to culture and knowledge base. The need to internationalize gradually and the choice of foreign markets are explained with the idea of "psychic distance", which results from cultural differences, or different business practices in the home and host countries. Wishing to minimise the risk of operating abroad, the firms first expand to markets, which are closer to them with respect to "psychic" and by that reduce the likelihood of failure. Acquired experience is then used to enter markets, for which "psychic distance" is bigger.

The authors argue that a firm gradually increases its control over sales and manufacturing going through four stages: from incidental exports followed by sales through independent agents, setting up a branch or a trade division up to transferring production abroad. As the company is receiving more knowledge and is learning more from international activities it overcomes barriers to its growth and operates more efficiently on other markets. That often translates into propensity to penetrate more geographically distant markets and the use of more advanced forms of internationalization. The process evolves as an interplay between the development of knowledge about foreign markets and operations on one hand and an increasing commitment to resources on the other hand (Johanson and Vahlne, 1990).

The model implies that rather than investing in several countries simultaneously, firms should take small, incremental steps and invest within one or a few of their neighbouring countries (Ruzzier, 2006). The first stage, gives practically no market experience. In the second one the firm has an information channel to the market. Exports are delivered through independent agents. In the third stage of internationalisation, the firm establishes its trading subsidiary abroad and becomes more and more interested in acquiring knowledge about the market concerned. Final stage is crowned with the setting up of own manufacturing facilities abroad, which connects to deeper engagement of firm's assets. 
The Uppsala model provided inspiration to many economists who made references to the idea of the sequential nature of internationalisation in their theories. Subsequent theories proposed different stages of internationalisation and a different view on determinants of the process. Cavusgil (1984) by focusing on export involvement distinguished 3 stages of internationalisation: experimental, active and committed involvement. The first one is limited to exports, which are spontaneous and improvised. In the second stage foreign activities evolve into a purposeful strategy of a company. Exports are no longer accidental and become systematic. Final stage means active seeking of opportunities to act internationally in foreign markets, which practically implies an involvement into new forms of internationalisation (manufacturing subsidiaries, joint venture companies). Reid (1981) focused on exports and highlighted that they take place when we observe positive approach of managers, favourable conditions in the foreign market and production capacity surplus. For him internationalization consists of stages resulting from managers' response starting from export awareness, through export intention, trial export, its outcomes up to the acceptance/ rejection of this stage of internationalisation.

Another idea of a sequential model of internationalization was proposed by Bilkley and Tesar (1977). Internationalization stages distinguished by them are based on a combination of several criteria, e.g., experience in export sales or the number and types of target countries-markets. Initiating exports links to innovation processes in a firm. Czinkota's model (1982) describing the transition from a complete lack of interest in exports to an active exporter belongs to a similar group of ideas.

Sequential nature of a firm's foreign involvement is also visible in the work by Korth (1985). He distinguished four stages of internationalization: 1) an enterprise exhibits only passive and indirect international involvement, 2) an enterprise is directly involved in international expansion (most probably sets up an import/export unit), 3) an enterprise has got a subsidiary abroad and involvement in foreign markets is a vital part of its business, 4) an enterprise focuses on operations in many countries not in the domestic market.

Considerable number of stage theories of internationalization shows that they were and still are sources of inspiration to many researchers. They were also heavily criticised, which resulted in new ideas of internationalization of enterprises, such as, e.g., network business models (Möller and Rajala 2007; Johanson and Mattsson 1993; Ng and Zain 2006) or models of firms born global (Rennie 1993; Knight and Cavusgil 1996, 2004, 2014; Freeman, Edwards and Schroder 2006; Zhou, Wu and Luo 2007).

Criticism of Uppsala models mainly boils down to questioning the concept of stages of internationalization and psychic distance. Johansson and Mattson (1988) state that it is of little use when both the market and the firm are highly internationalized. Reid (1983) claims it is too deterministic and general. Sullivan and Bauerschmidt (1990) criticise the influence of geographical distance of markets upon internationalization. Similar observations can be traced in the works by Dunning (1995), who claims that the distance between markets is not so important because of globalisation. The latter is characterised with trade liberalisation, access to the Internet and common use of English as a universal business language, which taken together blur borders and give trouble-free access to many markets.

Also the idea of psychic distance is not appreciated by many contemporary researchers of internationalization. The Uppsala model built around such a conviction has become questionable as it cannot properly explain the course of internationalization under the conditions of modern economy.

In spite of the criticism of the Uppsala model highlighting its uselessness under changing market circumstances, Madsen and Servais (1997) claim its assumptions may apply to born global firms. On top of that, recently updated versions of the Uppsala model are also taking account of components characteristic of other theoretical approaches, e.g., the ones identified in network models (Vahlne and Johanson, 2002; Johanson and Vahlne, 2009). Latest works draw attention to the fact that internationalization requires the involvement of participants to various relations, who no longer operate in a completely autonomous way. 
The specificity of operating in third markets determines the need to establish relations with suppliers and customers, who also develop new links with other entities. As a result we are dealing with co-dependence in business relations. The latest version of the sequential model presents foreign expansion as a way to strengthen firm's position in a network.

Taking account of the above, we may assume that the Uppsala model is interesting as it may be applied in many research studies. That is also true of Polish enterprises wishing to enter foreign markets. Observations of internationalization of Polish firms have led us to believe that most of them start international operations with indirect exports, which later become direct to gradually go through subsequent stages of involvement with foreign markets. Moreover firms which embark on internationalization start and continue to invest in one or a few neighbouring countries rather than investing in distant markets and/or several markets simultaneously. In accordance with the Uppsala model, 'closer' markets are those that are perceived to be close, i.e., where culture and knowledge are similar. These are markets located at a shorter psychic distance, which may sometimes diverge from straight geographic distance.

\section{METHODOLOGY}

As we mentioned, there are many theories of internationalization: stage theories, (Uppsala model and innovative models), early internationalization theories and network theories. In the range of internationalization theories, the Uppsala model is the most frequently used and praised by businesses and scientists. It is dominant (Fillis, 2001) and significance and simplicity is its unquestionable strength (Forsgren 2002). It has been claimed to be very general and therefore applicable to many different firms and different situations (Pedersen and Petersen 1998). Despite being often criticised, the Uppsala model still stands today (Forsgren, 2002; Sharma and Blomstermo, 2003).

Uppsala model perceives internationalization as a gradual and long-lasting process. It assumes, that companies start their international performance in the form of OFDI on the closest markets, where the psychic distance is not so big. Moreover, at the beginning, the forms which support exports prevail over delocalisation of production. At the final stage of internationalization process, when the company already has a wide range of knowledge about host economy and the market.

Therefore, to verify the hypothesis put at the beginning of the article we used the data covering the geographical and sectoral breakdown of Polish OFDI as well as the information on turnover achieved by foreign entities and the share of exports in a given economy. The latter information can show the scale of market orientation of an investor. The smaller share of exports in turnover, the more an investor is oriented at conquering the local market. High share of exports might suggest the inclusion of investment into the chain of generating international value in a corporation, which is typical of a more advanced form of internationalization.

Statistical analysis used in the paper is based on data originating from GUS (Central Statistical Office of Poland). It was prepared directly for the needs of the research project. Data cover the period of 2009-2011.

\section{STRUCTURE AND DIRECTIONS OF POLISH FOREIGN INVESTMENTS}

Despite difficulties caused by the global economic crisis, Polish enterprises continued to increase their direct capital engagement in foreign markets in the period 2009-2011. In 2009 as many as 1,313 companies declared they have entities abroad and in 2011 their number grew to 1,501, see Table 1 . The year 2012 proved less favourable for Polish foreign investors as their population shrank to 1,437. At the same time, the 
number of foreign entities was continuously growing from 2,747 in 2009 to 3,194 in 2012. The share of businesses in the manufacturing sector was ca. 34\%-35\% as for the number of investors, and 31\%-32\% - as for the number of foreign entities. Almost $85 \%$ of foreign owned entities were established as subsidiaries, and about $10 \%-11 \%$ as branches.

Over the period covered by the study ca. $80 \%$ of all investing companies were members of capital groups (which provides evidence about their stronger market power) out of which slightly more than $1 / 3$ rd belonged to international capital groups with the dominant companies based outside of Poland.

Table 1

Polish foreign investors and foreign entities of Polish companies in the period 2009-2011

\begin{tabular}{|c|c|c|c|c|c|c|}
\hline & \multicolumn{3}{|c|}{ Number of foreign investors } & \multicolumn{3}{|c|}{ Number of foreign entities } \\
\hline & 2009 & 2010 & 2011 & 2009 & 2010 & 2011 \\
\hline TOTAL & 1,313 & 1,443 & 1,501 & 2,747 & 2,988 & 3,178 \\
\hline \multicolumn{7}{|l|}{ of which: } \\
\hline MANUFACTURING & 456 & 488 & 522 & 839 & 921 & 1,016 \\
\hline food products & 49 & 49 & 53 & 77 & 79 & 90 \\
\hline beverages & 7 & 7 & 7 & 19 & 13 & 17 \\
\hline textiles & 5 & 9 & 9 & 6 & 10 & 11 \\
\hline wearing apparel & 7 & 7 & 6 & 10 & 10 & 8 \\
\hline leather and related products & 5 & 4 & 3 & 6 & 5 & 3 \\
\hline products of wood, cork, straw and wicker & 14 & 16 & 14 & 22 & 23 & 22 \\
\hline paper and paper products & 10 & 10 & 9 & 13 & 15 & 10 \\
\hline printing and reproduction of recorded media & 4 & 6 & 6 & 7 & 10 & 12 \\
\hline coke and refined petroleum products & 4 & 5 & 7 & 41 & 47 & 53 \\
\hline chemicals and chemical products & 23 & 25 & 28 & 37 & 46 & 50 \\
\hline pharmaceutical products & 7 & 7 & 8 & 23 & 16 & 31 \\
\hline rubber and plastic products & 47 & 48 & 59 & 99 & 100 & 131 \\
\hline other non-metallic mineral products & 25 & 29 & 30 & 33 & 43 & 38 \\
\hline basic metals & 10 & 14 & 18 & 29 & 37 & 29 \\
\hline metal products & 88 & 98 & 103 & 149 & 164 & 172 \\
\hline computer, electronic and optical products & 14 & 16 & 12 & 23 & 41 & 25 \\
\hline electrical equipment & 24 & 27 & 31 & 47 & 45 & 77 \\
\hline machinery and equipment & 40 & 41 & 45 & 68 & 74 & 86 \\
\hline motor vehicles, trailers and semi-trailers & 11 & 11 & 18 & 27 & 29 & 44 \\
\hline other electrical equipment & 7 & 7 & 9 & 13 & 15 & 18 \\
\hline furniture & 17 & 16 & 18 & 39 & 44 & 48 \\
\hline other products & 8 & 9 & 9 & 12 & 16 & 16 \\
\hline $\begin{array}{l}\text { repair, maintenance and installation of ma- } \\
\text { chinery and equipment }\end{array}$ & 30 & 27 & 20 & 39 & 39 & 25 \\
\hline
\end{tabular}

Source: own calculations based on GUS data.

Manufacturers of metal products were the most engaged in FDI, in 2011103 enterprises owned in total 172 foreign entities. Second largest group were food producers (food processing and beverages) - 60 companies owned 107 foreign entities. The number of manufacturers of rubber and plastic products (59 investors 
owned 131 entities) and manufacturers of machinery and equipment (45 investors with 86 foreign entities) was also relatively substantial.

On average there were fewer than 2 foreign entities per investor. Against this background, producers of coke and refined petroleum products feature positively with 8-10 foreign entities per investor. The sector does not have a numerous representation in the Polish economy but it is dominated by large, strong players with substantial ownership advantages, which have been internationally active for many years already (PKN Orlen, KGHM). Their investments are primarily linked with the exploitation of natural resources in various parts of the world or with the acquisitions of foreign competitors and markets.

Polish enterprises have invested their capital in almost 100 countries, however, a detailed analysis of geographical breakdown of their investments clearly indicates that European markets, in particular those in the neighbouring countries, were especially attractive to Polish enterprises. Almost $85 \%$ of all foreign entities are based in Europe (with ca. 88\%-90\% of entities owned by manufacturing companies) while over a half of foreign entities of Polish companies (and slightly more than 60\% of manufacturing companies) were located in our immediate neighbourhood (Germany, the Czech Republic, Slovakia, Ukraine, Belarus, Lithuania, and Russia), see Table 2. Interestingly enough, neighbouring non-EU countries (Russia, Ukraine, Belarus) were more interesting for industrial companies than other EU Member States (not bordering Poland). In total all the EU countries host slightly less than $60 \%$ of foreign entities. That may confirm the thesis that Polish enterprises follow the strategy in line with the assumptions of the Uppsala stage model of internationalisation.

The majority of foreign entities are located in Germany. Their number increased from 372 in 2009 to 427 in 2011. Further on the list we can find Ukraine (355 entities in 2011), Czech Republic (270 entities in 2011), Russia (242 entities in 2011), Romania (159 entities in 2011), Slovakia (150 entities in 2011), Cyprus (131 entities in 2011), Hungary (118 entities in 2011), and Lithuania (116 entities in 2011). At the end of the top-ten list there is Belarus with 78 entities in 2011.

Table 2

Foreign entities owned by Polish investors by the country of investment in the years 2009-2011

\begin{tabular}{|l|c|c|c|c|c|c|}
\hline \multirow{2}{*}{} & \multicolumn{3}{|c|}{ Total number of foreign entities } & \multicolumn{2}{c|}{$\begin{array}{c}\text { Number of foreign entities owned by manu- } \\
\text { facturing companies }\end{array}$} \\
\cline { 2 - 7 } & 2009 & 2010 & 2011 & 2009 & 2010 & 2011 \\
\hline TOTAL & 2 & 3 & 4 & 5 & 6 & 7 \\
\hline Austria & $\mathbf{2 , 7 4 7}$ & $\mathbf{2 , 9 8 8}$ & $\mathbf{3 , 1 7 8}$ & $\mathbf{8 3 9}$ & $\mathbf{9 2 1}$ & $\mathbf{1 , 0 1 6}$ \\
\hline Belgium & 29 & 28 & 20 & 13 & 13 & 4 \\
\hline Belarus & 17 & 21 & 21 & 8 & 11 & 11 \\
\hline Bulgaria & 84 & 88 & 78 & 35 & 36 & 30 \\
\hline China & 32 & 36 & 42 & 13 & 11 & 12 \\
\hline Croatia & 34 & 40 & 41 & 15 & 21 & 20 \\
\hline Cyprus & 30 & 30 & 28 & 3 & 4 & 4 \\
\hline Czech Republic & 83 & 102 & 131 & 11 & 5 & 15 \\
\hline Denmark & 228 & 246 & 270 & 82 & 91 & 98 \\
\hline Finland & 22 & 23 & 25 & 6 & 6 & 7 \\
\hline France & 11 & 13 & 13 & 2 & 3 & 4 \\
\hline Spain & 45 & 67 & 68 & 15 & 24 & 27 \\
\hline
\end{tabular}




\begin{tabular}{|l|c|c|c|c|c|c|}
\hline \multicolumn{1}{|c|}{1} & 2 & 3 & 4 & 5 & 6 & 7 \\
\hline The Netherlands & 55 & 67 & 73 & 3 & 6 & 8 \\
\hline Ireland & 16 & 14 & 16 & 2 & 1 & 6 \\
\hline Kazakhstan & 21 & 26 & 27 & 3 & 3 & 7 \\
\hline Lithuania & 109 & 105 & 116 & 30 & 33 & 38 \\
\hline Luxembourg & 43 & 51 & 71 & 2 & 2 & 6 \\
\hline Latvia & 26 & 26 & 25 & 8 & 7 & 7 \\
\hline Malta & 24 & 22 & 17 & 4 & 3 & 2 \\
\hline Germany & 372 & 400 & 427 & 139 & 149 & 166 \\
\hline Norway & 22 & 23 & 27 & 7 & 9 & 10 \\
\hline Russia & 210 & 231 & 242 & 86 & 87 & 98 \\
\hline Romania & 131 & 150 & 159 & 32 & 38 & 39 \\
\hline Serbia & 27 & 23 & 21 & 3 & 4 & 5 \\
\hline Slovakia & 122 & 125 & 150 & 36 & 39 & 49 \\
\hline U.S. & 59 & 71 & 68 & 15 & 18 & 18 \\
\hline Switzerland & 24 & 24 & 28 & 6 & 5 & 9 \\
\hline Sweden & 27 & 41 & 48 & 7 & 10 & 16 \\
\hline Turkey & 16 & 20 & 20 & 4 & 5 & 6 \\
\hline Ukraine & 348 & 356 & 355 & 140 & 148 & 144 \\
\hline Hungary & 111 & 114 & 118 & 24 & 25 & 26 \\
\hline United Kingdom & 62 & 64 & 67 & 17 & 21 & 28 \\
\hline Italy & 23 & 36 & 36 & 8 & 10 & 10 \\
\hline UAE & 11 & 14 & 14 & 6 & 7 & 8 \\
\hline
\end{tabular}

Source: own calculations based on GUS data.

On average $1 / 3$ of all investments were made by industrial companies but in some countries their share very much diverged from the average. Manufacturers willingly located their entities in Germany, Ukraine, Czech Republic, and Russia where they accounted for ca. $40 \%$ of all entities owned by Polish investors. Interestingly, in the United Arab Emirates entities of industrial companies represented almost $60 \%$ of all businesses, in which Polish capital was involved (with metal products manufacturers forming the biggest group), in Belgium ca. 52\%, and ca. 50\% in China (out of which $1 / 4$ th were metal products manufacturers and $1 / 5$ th manufacturers of machinery and equipment). On the other hand, Cyprus, Malta, Luxembourg, and the Netherlands turned out to be the least interesting for manufacturers as investments in these countries did not exceed several dozen p.c. of all foreign investments by Polish enterprises. The above is not surprising if we remember that small countries offer attractive legal and tax solutions mostly to service providers (in particular in finance and $\mathrm{BPO} / \mathrm{SSC}$ branches).

Structure of OFDI in the manufacturing sector in neighbouring markets was dominated by manufacturers of metal products (especially in Czech, German, Slovak, Russian but also Ukrainian and Romanian markets). Manufacturers of rubber and plastic products were also very active (above all in Belarus, Russia, Romania, and Ukraine), similarly to the manufacturers of machinery and equipment including electrical equipment (in Russia and Ukraine and to a lesser extent also in Germany).

It is also worth noting that not all entities owned by industrial enterprises pursue manufacturing operations. Manufacturing entities dominate in less developed countries, which offer cheap labour, e.g., Belarus, Romania or China (almost $100 \%$ of entities in Belarus and China and ca. $75 \%-80 \%$ in Romania). In Russia, Germany and Ukraine ca. 60\%-70\% of entities owned by Polish manufacturing companies were involved in manufacturing (the rest were mainly trade oriented). In small countries situated relatively closely 
to Poland the proportions were reversed. In Lithuania, Slovakia, Hungary, and in the Czech Republic the share of manufacturing entities did not exceed ca. $40 \%$ of all branches established by Polish industrial investors. Over the studied period the share of industrial investment increased only in Lithuania while the rest of Central and East European countries reported a decrease (down to only ca. 20\% in 2011 in Hungary) or remained at a similar level. Domination of non-manufacturing entities in countries located at a short geographic and culture distance confirms expected results coming from the analysis of the Uppsala model. For numerous enterprises the first step to advanced internationalisation, which precedes production relocation leads through the establishing of trade entities in the markets in neighbouring countries.

Table 3

Turnover and the share of exports in the turnover of foreign entities of Polish enterprises in the years 2009-2011

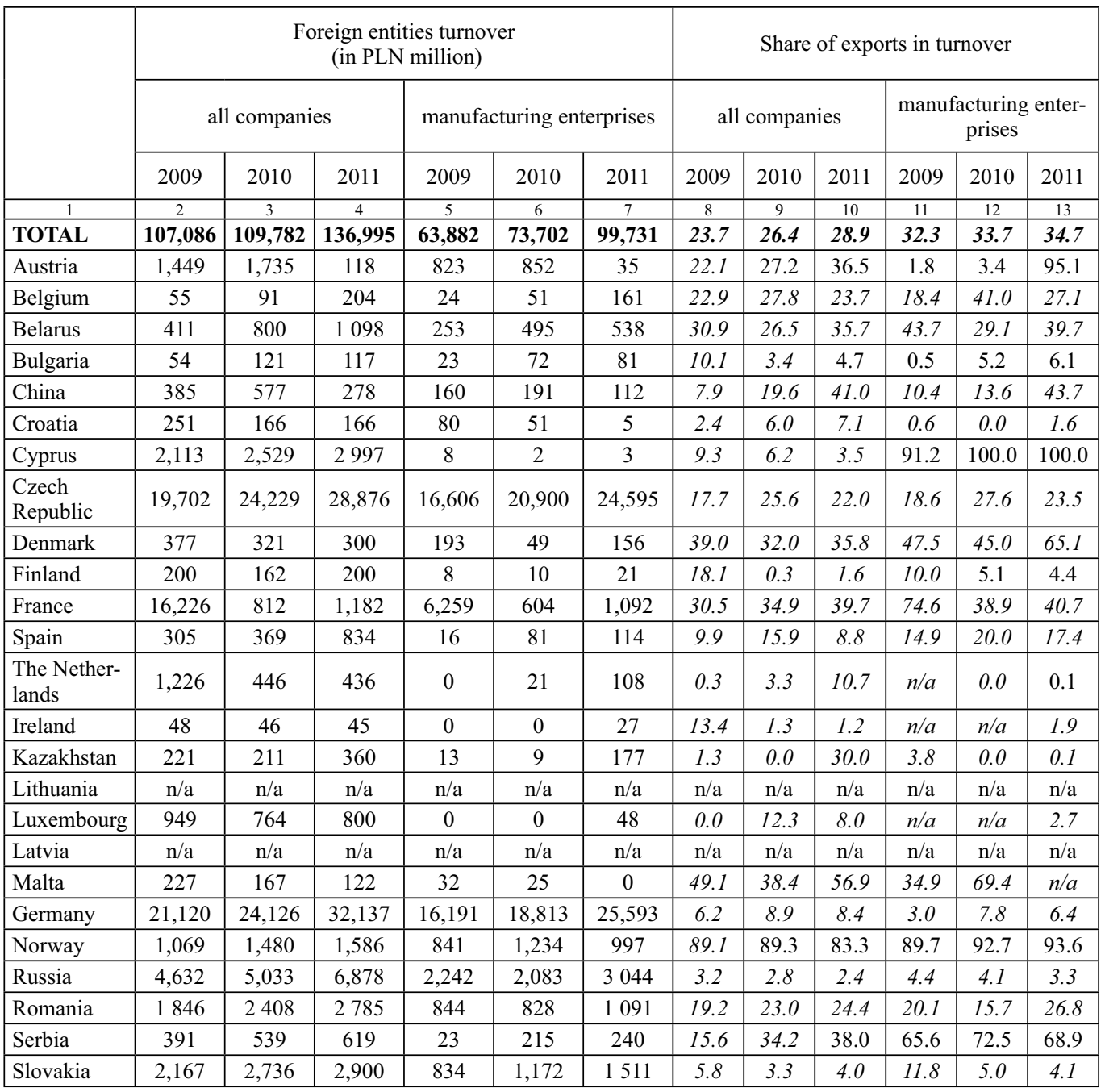




\begin{tabular}{|l|c|c|c|c|c|c|c|c|c|c|c|c|}
\hline \multicolumn{1}{|c|}{1} & 2 & 3 & 4 & 5 & 6 & 7 & 8 & 9 & 10 & 11 & 12 & 13 \\
\hline U.S. & 6,224 & 6,780 & 3,495 & 267 & 610 & 838 & 0.4 & 3.3 & 6.0 & 5.4 & 31.4 & 20.1 \\
\hline Switzerland & 324 & 537 & 564 & 83 & 47 & 53 & 3.8 & 4.7 & 31.1 & 14.7 & 25.5 & 30.8 \\
\hline Sweden & 905 & 1,586 & 1,884 & 39 & 89 & 232 & 73.8 & 5.6 & 8.0 & 62.4 & 60.6 & 54.6 \\
\hline Turkey & 168 & 192 & 167 & 37 & 20 & 9 & 11.0 & 24.8 & 21.5 & 0.0 & 1.3 & 0.0 \\
\hline Ukraine & 2,937 & 2,998 & 3,748 & 1,456 & 1,781 & 1,527 & 26.9 & 26.3 & 16.6 & 34.4 & 19.7 & 12.5 \\
\hline Hungary & 1,101 & 1,009 & 1,197 & 401 & 304 & 475 & 4.3 & 3.7 & 5.9 & 4.2 & 2.7 & 7.2 \\
\hline $\begin{array}{l}\text { United } \\
\text { Kingdom }\end{array}$ & 1,119 & 1,176 & 1,236 & 371 & 924 & 1038 & 22.9 & 18.4 & 16.2 & 6.7 & 14.2 & 13.1 \\
\hline Italy & 385 & 359 & 474 & 64 & 47 & 95 & 22.4 & 25.9 & 20.4 & 24.0 & 39.5 & 19.5 \\
\hline UAE & 496 & 864 & 1,217 & 440 & 819 & 1159 & 86.4 & 22.4 & 37.2 & 85.9 & 19.0 & 36.9 \\
\hline
\end{tabular}

Source: own calculations based on GUS data.

German market dominated not only in terms of the number of Polish investors and foreign entities but also when it comes to the total turnover of the entities, see Table 3. Czech market ranked second but the sales were much below the German market. We need to highlight that the total turnover in these two markets accounted for almost a half of all revenues of foreign entities of Polish enterprises.

Russia turned out to be the third biggest market with sales turnover on average 5 times lower than in the Czech Republic (and almost 10 times lower for manufacturing entities). In Ukraine, which ranked fourth in this classification, revenue reported by foreign entities accounted for half of that in Russia. Markets important to Polish investors (in order of importance) are also U.S. and Cyprus, however, they remained little interesting to manufacturing enterprises (USA) or even marginal (Cyprus).

Nevertheless, the analysis of data on the performance of foreign entities lets us conclude that foreign investments were made primarily to win local markets. The share of exports, although increasing, did not exceed $30 \%$ of the sales turnover of foreign entities in the analysed period. The share was a bit higher for manufacturing businesses and amounted to almost 35\% in 2011. Increase in the share of exports in the turnover (although minor) should be assessed positively as it may result from deeper international engagement and better ability to use the potential of foreign markets.

When analysing exports oriented approach of investors in individual markets, we should highlight its substantial geographical differentiation. In the dominant German market exports accounted for only 3\%$8 \%$ of the turnover while in the Czech Republic for not more than $27 \%$ (interestingly enough, almost all exports from the Czech Republic originated from entities dealing with oil production and processing, i.e. entities linked with PKN Orlen). Low share of exports was also reported for Russia (3\%-4\% of revenue), Ukraine (where additionally a significant decrease was recorded from $34 \%$ in 2009 to $12.5 \%$ in 2011), Hungary, and Slovakia.

On the other hand, entities of manufacturing enterprises located in Scandinavian countries (Norway, Sweden and Denmark) as well as in Serbia and Cyprus reported relatively high exports. It is worth stressing, however, that the total sales turnover in these countries was low, hence high average exports may result from strategies followed by individual entities.

\section{CONCLUDING REMARKS}

Internationalization is an important component of the growth and development strategy of the company. Polish enterprises seem to prove that - despite difficulties caused by the global economic crisis they increased direct capital involvement in foreign markets in the years 2009-2011. Data presented in the paper 
provide evidence that Polish firms prefer a conservative model of internationalization, well subscribed to the framework of the Uppsala model. They have invested in almost 100 countries across the world but a detailed analysis of geographical breakdown of their investments clearly indicates that European markets, in particular those in the neighbouring countries close in geographic and cultural terms, were especially attractive to Polish enterprises. Almost $85 \%$ of all foreign entities are based in Europe while over a half of foreign entities of Polish companies (and slightly more than $60 \%$ of industrial companies) were located in our immediate neighbourhood (Germany, the Czech Republic, Slovakia, Ukraine, Belarus, Lithuania, and Russia).

On top of that, data show that not all entities owned by industrial companies pursued manufacturing operations. Manufacturing entities dominate in less developed countries, which offer cheap labour (Belarus, Romania, and China). Similar situation was reported for Russia, Germany and Ukraine where ca. 60\%-70\% of entities owned by Polish manufacturing companies were involved in manufacturing. In small countries situated relatively closely to Poland (Lithuania, Slovakia, Hungary, and in the Czech Republic) the share of manufacturing entities did not exceed $40 \%$ of all subsidiaries and branches established by Polish industrial investors. Such a domination of non-manufacturing entities in countries of geographic and cultural proximity confirms the findings of the analysis of the Uppsala model, which assumes that production relocation is preceded by establishing trade units in neighbouring countries. Moreover, the highest turnover in foreign entities of Polish enterprises was also recorded in markets of our immediate neighbours (Germany, the Czech Republic). It may confirm that Polish companies base their foreign expansion on the idea of stage models.

\section{REFERENCES}

Andersson S., Wictor I. (2003), Innovative Internationalisation in New firms: Born Globals - the Swedish Case, "Journal of International Entrepreneurship", Vol.1(3), pp. 249-275.

Bilkey W.J., Tesar G. (1977), The Export Behavior of Smaller Wisconsin Manufacturing Firms, "Journal of International Business Studies", Vol. 8(1), pp. 93-98.

Calof J., Beamish P.W. (1995), Adapting to foreign markets: explaining internationalization, "International Business Review", Vol. 4(2), pp. 115-131.

Cannone G., Ughetto E. (2014), Born globals: A cross-country survey on high-tech start-ups, "International Business Review”, Vol. 23(1), ss. 272-283.

Cavusgil S.T. (1984), Differences Among Exporting Firms Based on Their Degree of Internationalization, "Journal of Business Research", Vol.12(2), pp. 195-208.

Czinkota M.R. (1982), Export development strategies: US promotion Policy, Praeger, New York.

Dunning J.H. (1981), International Production and the Multinational Enterprise, George Allen and Unwin, London.

Dunning J.H. (1995), Trade, Location of Economic Activity and The Multinational Enterprise: A search for an eclectic approach, in: Readings in International Enterprise, Drew P. (ed.), London, pp. 250-274.

Fillis I. (2001), Small firm internationalisation: an investigative survey and future research directions, "Management Decision”, Vol. 39(9), pp.767-783.

Fletcher R. (2001), A holistic approach to internationalization, "International Business Review", Vol. 10(1), pp. 25-49.

Forsgren M. (2002), The Concept of Learning in the Uppsala internationalization process model: a critical review, "International Business Review”, Vol. 11(3), pp. 257-277.

Freeman S., Edwards R., Schroder B. (2006), How Smaller Born-Global Firms Use Networks and Alliances to Overcome Constraints to Rapid Internationalization, "Journal of International Marketing", Vol. 14(3), pp. 33-63.

Fulk J. (2001), Global network organizations: Emergence and future prospects, "Human Relations" Vol.54(1), pp. 91-99.

Gorynia M. (2007), Strategie zagranicznej ekspansji przedsiębiorstw, PWE, Warszawa. 
Gulati R., Dania D., Wang L. (2002), Organizational Networks, in: Blackwell Companion to Organizations, Baum J.A.C (ed.), Blackwell Publishers, Boston, pp. 281-303.

Hammond C., Grosse R. (2003), Rich man, poor man: Resources on Globalization, "Reference Service Review”, Vol. 31(3), pp. 285-295.

Johanson I., Vahlne I. (1990), The Mechanism of Internationalization, "International Marketing Review", Vol. 7(4), pp. 11-24.

Johanson J., Mattson L.G. (1988), Internationalization in industrial systems -- A network approach, in: Industrial networks: A new view of reality, Axellson B., Easton G. (eds.). Routledge, London.

Johanson J., Mattsson L.G. (1993), Internationalization in industrial systems - a network approach, strategies in global competition, in: The Internationalization of the Firm: A Reader, Buckley P.N., Ghauri P.J. (eds.), Academic Press, London.

Johanson J., Vahlne J.E. (1977), The internationalization process of the firm - A model of knowledge development and increasing market commitments, "Journal of International Business Studies", Vol. 8(1), pp. 23-32.

Johanson J., Vahlne J.E. (2009), The Uppsala Internationalization Process Model Revisited: From Liability of Foreignness to Liability of Outsidership, "Journal of International Business Studies", Vol. 40(9), pp. 1411-1431.

Johanson J., Wiedersheim-Paul F. (1975), The Internationalization of the Firm - Four Swedish Cases, "The Journal of Management Studies", Vol. 12(3), pp. 305-323.

Knight G.A., Cavusgil S.T. (1996), The Born Global Firm: A Challenge to Traditional Internationalization Theory, in: Advances in International Marketing, Cavusgil S.T., Madsen T. (eds.), Vol. 8, JAI Press, Greenwich, pp. 11-26.

Knight G.A., Cavusgil S.T. (2004), Innovation, organizational capabilities, and the born-global firm, "Journal of International Business Studies", Vol. 35(2), pp. 124-141.

Knight G.A., Cavusgil S.T. (2014), The born global firm: An entrepreneurial and capabilities perspective on early and rapid internationalization, "Journal of International Business Studies", Vol. 46, pp. 3-16.

Korth Ch.M. (1985), International Business. Environment and Management, Englewood Cliffs, N.J.

Madsen T.K., Servais P. (1997), The Internationalization of Born Globals: An Evolutionary Process?, "International Business Review", Vol. 6(6), pp. 561-583.

Mejri K., Umemoto K. (2010), Small-and Medium-Sized Enterprise Internationalization: Towards the Knowledge-Based Model, "Journal of International Entrepreneurship", Vol. 8(2), pp. 156-167.

Melin L. (1992), Internationalization as a strategy process, "Strategic Management Journal”, Vol. 13, pp. 99-118.

Möller K., Rajala A. (2007), Rise of strategic nets - New modes of value creation, "Industrial Marketing Management, Vol. 36(7), pp. 895-908.

Ng S.I., Zain M. (2006), The Impacts of Network Relationships on SMEs' Internationalization Process, “Thunderbird International Business Review", Vol. 48(2), pp. 183-205.

Ojala, A. (2009), Internationalization of knowledge-intensive SMEs: The role of network relationships in the entry to a psychically distant market, "International Business Review" Vol.18(1), pp. 50-59.

Pedersen T., Petersen B. (1998), Explaining gradually increasing resource commitment to a foreign market, "International Business Review", Vol. 79(5), pp. 483-501.

Reid S. (1981), The decision-market and export entry and expansion, "Journal of International Business Studies", Vol. 12(2), pp. 101-112.

Reid S. (1983), Firm Internationalization, Transaction Costs And Strategic Choice, "International Marketing Review", Vol. 1(2), pp. 44-56.

Rennie M.W. (1993), Global competitiveness: Born global, "McKinsey Quarterly", Vol. 4, pp. 45-52.

Ruzzier M. (2010), SME internationalization. Conceptual integration and empirical verification, LAP LAMBERT Academic Publishing, Saarbrucken.

Ruzzier M., Hisrich R.D., Antončič B. (2006), SME internationalization research: past, present, and future, "Journal of Small Business and Enterprise Development", Vol.13(4), pp. 476-497. 
Sharma D.D., Blomstermo A. (2003), The internationalization process of born globals: a network view, "International Business Review", Vol.12(6), pp. 739-753.

Sleuwaegen L., Onkelinx J. (2014), International commitment, post-entry growth and survival of international new ventures, "Journal of Business Venturing", Vol. 29(1), ss. 106-120.

Sullivan D., Bauerschmidt A. (1990), Incremental internationalization: a test of Johanson and Vahlne's thesis, "Management International Review", Vol. 30(1), pp. 19-30.

Trąpczynski P., Wrona T. (2013), From going international to being international - strategies for international competitiveness, "Poznan University of Economics Review", Vol. 13(1), pp. 89-114.

Turner C. (2012), Deinternationalisation: towards a coevolutionary framework, "European Business Review", Vol. 24(2), pp. $92-105$.

Vahlne J.-E., Johanson J. (2002), New technology, new business environments and new internationalization processes?, in: Critical perspectives on internationalization, Havila V., Forsgren M., Håkansson H. (eds), Pergamon, London, pp. 209-228.

Welch L.S., Luostarinen R.K. (1988), Internationalization: Evolution of a Concept, "Journal of General Management", Vol. 14(2), pp. 36-64.

Zhou L., Wu W., Luo X. (2007), Internationalization and the Performance of Born Global SMEs: The Mediating Role of Social Networks, "Journal of International Business Studies", Vol. 38(4), pp. 673-690. 